\title{
Assessing the Role of Kettle Holes for Providing and Connecting Amphibian Habitats in Agricultural Landscapes
}

\author{
Biljana Savić ${ }^{1}$, Alevtina Evgrafova ${ }^{1}$, Cenk Donmez ${ }^{1,2}$, Filip Vasić ${ }^{1}\left(\mathbb{D}\right.$, Michael Glemnitz $^{1}$ (D) and Carsten Paul ${ }^{1, *}$ \\ 1 Leibniz Centre for Agricultural Landscape Research ZALF, Eberswalder Straße 84, 15374 Müncheberg, \\ Germany; biljana.savic.paih@gmail.com (B.S.); alevtina.evgrafova@zalf.de (A.E.); \\ cenk.doenmez@zalf.de (C.D.); filipvasic24@yahoo.com (F.V.); mglemnitz@zalf.de (M.G.) \\ 2 Remote Sensing and GIS Laboratory, Landscape Architecture Department, Cukurova University, \\ Adana 01330, Turkey \\ * Correspondence: Carsten.Paul@zalf.de
}

Citation: Savić, B.; Evgrafova, A.; Donmez, C.; Vasić, F.; Glemnitz, M.; Paul, C. Assessing the Role of Kettle Holes for Providing and Connecting Amphibian Habitats in Agricultural Landscapes. Land 2021, 10, 692. https://doi.org/10.3390/land10070692

Academic Editors: Francesco M. Angelici and Corrado Battisti

Received: 4 June 2021

Accepted: 24 June 2021

Published: 30 June 2021

Publisher's Note: MDPI stays neutral with regard to jurisdictional claims in published maps and institutional affiliations.

Copyright: (c) 2021 by the authors. Licensee MDPI, Basel, Switzerland. This article is an open access article distributed under the terms and conditions of the Creative Commons Attribution (CC BY) license (https:// creativecommons.org/licenses/by/ $4.0 /)$.

\begin{abstract}
The intensification of agriculture over the last few decades has caused habitat loss, which poses a significant threat to the survival of populations and species. Where habitats are connected, populations may escape the destruction of their habitat by migrating to another one. Consequently, the functional connectivity of landscapes has become an important focus for species conservation. Kettle holes are hotspots of biodiversity that provide suitable conditions for wildlife species (i.e., amphibians, insects, aquatic plants) and contribute to landscape heterogeneity. They are also considered to function as stepping stone habitats that contribute to habitat connectivity. This study assesses the contribution of kettle holes for (i) habitat provision and (ii) the functional connectivity of three amphibian species with different movement ranges, and (iii) the study identifies areas where the creation of stepping stone biotopes could improve functional connectivity. The contribution of kettle holes was assessed using GIS-based clustering within three research areas in Germany. It was found that the importance of kettle holes for providing amphibian habitats in the three studied areas was equal to or higher than that of other wetland habitats. The state of functional connectivity and the contribution of kettle holes differed strongly depending on the species' range. For the shortrange species, landscapes were highly fragmented, and the contribution of kettle holes was much smaller than that of corridor habitats. For the long-range species, all habitats suited for amphibian reproduction were connected, and the contribution of kettle holes was similar to that of corridor habitats. However, the contribution of both was mostly redundant. Overall, the results showed that kettle holes play a crucial role in habitat provision and function as important stepping stone biotopes in agricultural landscapes. The clustering method applied in this study provides a simple tool for landscape planning and environmental protection agencies, which can be easily adapted to analyze functional connectivity and habitat interactions for different species or landscapes.
\end{abstract}

Keywords: pothole; wetland; functional connectivity; stepping stone biotope; ecosystem service

\section{Introduction}

In agricultural landscapes, kettle holes are "hotspots" of biodiversity [1,2] that provide habitats for wildlife species limited to aquatic or wet conditions, such as amphibians, wetland insects, and aquatic plants. The area of kettle holes is usually smaller than 0.01 ha; however, it can also reach sizes of up to 3-15 ha [3]. These pond-like depressions (i.e., kettle holes) in young moraine landscapes [1] formed 10,000-12,000 years ago in the Pleistocene [4]. They are mainly located in agricultural areas [3] and are characterized by strong wet-dry cycles [5]. Some are filled with water throughout the year and potentially flood the surrounding areas during wet periods; others are drying up completely for extended periods of time. The habitat heterogeneity hypothesis states that habitats with small sizes but high intrinsic heterogeneity correspond to a wider range of niches and species [6]. Not only does the ecological role of kettle holes support this hypothesis, but 
kettle holes are also considered to be keystone structures [7] that determine plant and animal species diversity by their presence.

The intensification of agriculture during the last few decades has caused the loss, degradation, and fragmentation of habitats, which all pose a major threat to the survival of populations and species communities [8,9]. In particular, the loss of wetlands has led to a reduction in the supply of specific ecosystem services, with negative consequences for the multifunctionality of agricultural landscapes [10]. According to Fahrig [11], habitat fragmentation is characterized by a decrease in the total amount of habitat and sizes of habitat patches, as well as by an increase in the number of habitat patches and patch isolation. For species such as amphibians that populate isolated habitats in highly diverse agricultural landscapes, the properties of ecological systems (e.g., habitat connectivity) are more likely to affect species diversity, abundance, and composition than habitat size [12]. As amphibians are characterized by the highest rates of overall endangered species worldwide (41\%) [13], they should be considered a focal organism group for biodiversity conservation in agricultural landscapes that are able to provide suitable habitats. Moreover, measures for improving habitat connectivity and foraging opportunities, as well as for reducing disturbance intensity in agricultural landscapes, are of high relevance for preserving populations in isolated amphibian habitats [14]. According to Hamm and Drossel [15], sufficient connectivity and dispersal allows for more species to coexist in a heterogeneous environment than in a homogeneous system. Increasing connectivity, both structural and functional, has gained importance as a strategy for biodiversity conservation [16]. The structural habitat connectivity represents the physical relationship between landscape elements, whereas the functional connectivity represents the degree to which the landscape facilitates or impedes the movement of organisms and matter between natural resource fields [16-18]. Multiple tools exist to assess the connectivity or fragmentation of natural habitats [17], such as graph theory [19], circuit theory [20], or modeling of potential organism movements [21].

Kettle holes support biodiversity in agricultural landscapes in two ways: (1) by providing valuable habitats and (2) by acting as stepping stone biotopes, connecting other wetland habitats and enabling genetic exchange [3]. In this way, kettle holes complement the habitat provision by other aquatic or semi-aquatic habitats, as well as the connecting role of other corridor habitats. While this dual role of kettle holes is well-recognized in academia, society, and environmental legislations [3], to the best of our knowledge, no attempt has yet been made to quantify the contributions of kettle holes to habitat provision and habitat connectivity, which both are regulation and maintenance ecosystem services. In this paper, this knowledge gap was addressed by using a geographic information system (GIS)-based approach to explore the following research objectives: (1) to assess the relative importance of kettle holes for amphibian habitat provision using the comparison of kettle holes to other wetland habitats in three studied landscapes; (2) to assess the relative contribution of kettle holes to the functional connectivity of wetland habitats for three amphibian species with different movement ranges; and (3) to identify to what extent the functional habitat connectivity could be improved by creating artificial stepping stone biotopes and where these would need to be created. For our analysis, we used three research areas within the German northern lowlands, where most kettle holes in Germany are located [3].

\section{Material and Methods}

\subsection{Study Area}

Three case study areas of approximately $130 \mathrm{~km}^{2}$ each were selected in the regions Uckermark, Märkisch-Oderland, and Prignitz within the federal state of Brandenburg, Germany (Figure 1). Uckermark is part of the backland of the Mecklenburg lake district, characterized by swampy depressions with loamy and sandy loam soils. MärkischOderland is part of the East Brandenburg plate. Soils are predominately bedload loams and boulder clays, as well as glacio-fluviatile and fluviatile sands. Prignitz is part of the North Brandenburg Plateau and Hill Country, with sandy soils occupying the largest part of the 
ground moraine plate [22]. The three case study areas comprise a total of 973 perennial kettle holes, most of which are located within agricultural fields. The share of kettle holes that are located within fields is high, ranging from $70 \%$ in Uckermark and Märkisch-Oderland to $95 \%$ in Prignitz. However, due to the small size of kettle holes, the share of agricultural area occupied by kettle holes is low, ranging from 0.2 to $0.3 \%$.

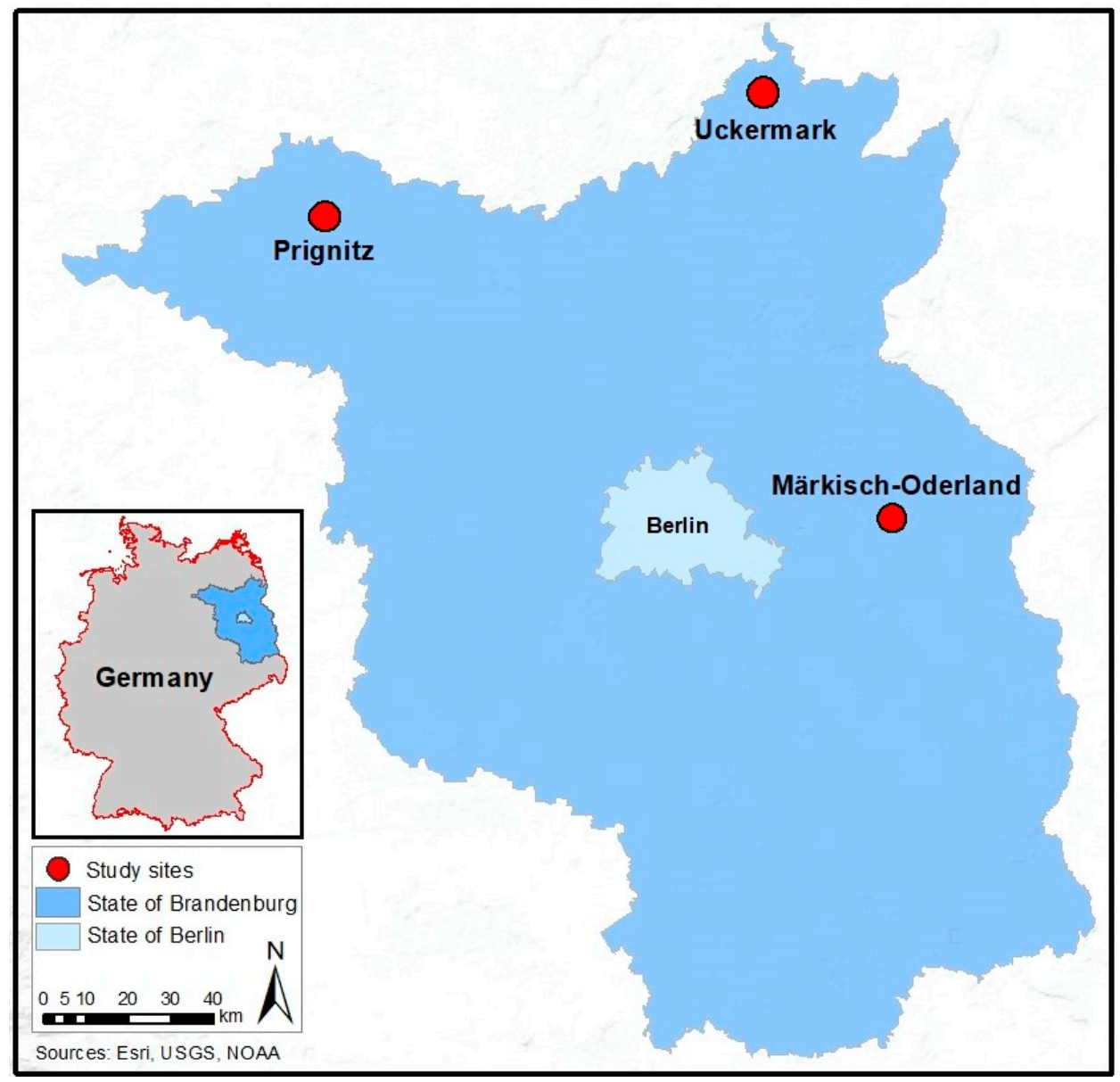

Figure 1. Location of the three study sites within in the Uckermark, Märkisch-Oderland, and Prignitz regions of the German federal state of Brandenburg.

\subsection{Indicator Species}

In this paper, wetland habitats were considered in a broader sense as defined under the Ramsar Convention: "wetlands are areas of marsh, fen, peatland or water, whether natural or artificial, permanent or temporary, with water that is static or flowing..." (Convention on Wetlands of International Importance especially as Waterfowl Habitat, 1971). In order to assess the functional connectivity of wetland habitats for amphibians, three species of toads were selected as indicators, namely garlic toad (Peleobatus fuscus), fire-bellied toad (Bombina bombina), and European green toad (Bufo viridis) (Table 1). These species are key species for the studied region [23] and are characterized by different behaviors, resulting in different movement ranges [14]. The selected species meet all four criteria of bioindicators according to [24], such as rarity, endangerment, protection, and key function. The degree of endangerment and protection status of the selected species is verified by the German Red List [25]. The migration of amphibian species shows great variability between species groups and amphibian individuals. The amphibian individuals have a well-developed orientation sense towards wet conditions, a so-called target-oriented movement. In this paper, we used as a species' range the lower value of the movement ranges for which, according to Berger et al. [14], genetic exchange between habitats is considered "good to 
medium". This corresponds to $200 \mathrm{~m}$ for garlic toads, $500 \mathrm{~m}$ for fire-bellied toads, and 1200 $\mathrm{m}$ for European green toads (Table 1). This conservative assumption was made because the method that we applied to assess functional connectivity connects reproduction habitats, corridor habitats, and kettle holes into clusters if the shortest distance between them can be crossed by a species, i.e., if it is lower than the species' range. Under wildlife conditions, animals will not be aware of the shortest route and may therefore have to cross longer distances.

Table 1. The characteristics of the three studied indicator species: appearance, movement ranges where genetic exchange considered "good to medium" according to Berger et al. [14], as well as endangerment and protection status according to the German Nature Conservation Act (BNatSchG).

\begin{tabular}{|c|c|c|c|}
\hline Specifications & $\begin{array}{c}\text { Garlic Toad } \\
\text { Peleobatus fuscus }\end{array}$ & $\begin{array}{l}\text { Fire-Bellied Toad } \\
\text { Bombina bombina }\end{array}$ & $\begin{array}{c}\text { European Green } \\
\text { Toad } \\
\text { Bufo viridis }\end{array}$ \\
\hline \multicolumn{4}{|l|}{ Appearance ${ }^{1,2,3}$} \\
\hline $\begin{array}{l}\text { Movement Range } \\
\text { (m) }\end{array}$ & $\begin{array}{c}\text { Short range } \\
200-500\end{array}$ & $\begin{array}{l}\text { Medium range } \\
\quad 500-800\end{array}$ & $\begin{array}{c}\text { Long range } \\
1200-1500\end{array}$ \\
\hline $\begin{array}{l}\text { Movement Range } \\
\text { used for this } \\
\text { Research (m) }\end{array}$ & 200 & 500 & 1200 \\
\hline $\begin{array}{c}\text { Endangerment and } \\
\text { Protection }\end{array}$ & $\begin{array}{l}\text { Severely endan- } \\
\text { gered/specially } \\
\text { protected }\end{array}$ & $\begin{array}{l}\text { Threatened with } \\
\text { extinction/strictly } \\
\text { protected }\end{array}$ & $\begin{array}{l}\text { Threatened with } \\
\text { extinction/strictly } \\
\text { protected }\end{array}$ \\
\hline
\end{tabular}

${ }^{1}$ Thum, Martin. Pelobates fuscus. Photograph. Shutterstock. ID: 532350289, Web. 31 March 2021. ${ }^{2}$ Swadzba, Marek R. European fire-bellied toad-Bombina bombina. Photograph. Shutterstock. ID: 696686965, Web. 23 June 2021. ${ }^{3}$ Hlavko, Miroslav. Beautiful European green toad Bufo viridis. Photograph. Shutterstock. ID: 1549644170, Web. 31 March 2021.

\subsection{Classification of Biotope Types}

The publicly accessible biotope mapping for the German federal state of Brandenburg (BTLN) was used. It provides information on land use and biotope types for the whole federal state [26]. The dataset is based on homogenized and updated color-infrared (CIR) aerial photographs taken in 2009 as well as on current data of the Official Digital Basic Landscape Model (ATKIS-DLM). Based on the three studied indicator species' needs, we defined three habitat classes: (i) habitats suitable for reproduction, referred to as reproduction habitats throughout this study; (ii) kettle holes; (iii) habitats suitable as movement corridors, referred to as corridor habitats. All areas not falling into categories i-iii are referred to as other habitats.

Reproduction habitats are biotopes characterized by standing water of natural or artificial origin that are constantly or occasionally filled with water. In this research, the reproduction habitats comprise water bodies in peat bogs, large reed beds in standing waters with subtypes, reed beds, grassland locations, trees and shrubs with less than $10 \%$ wood cover, swamps, ponds, and temporary and perennial small water bodies [27]. Although kettle holes are reproduction habitats for amphibians, they were assigned a class of their own in order to answer the research questions and analyze the contribution of kettle holes to habitat provision and habitat connectivity for amphibians. Please note that the BTLN only records kettle holes that are classified as permanent water bodies. Additional kettle holes exist which are water-filled only in some years, but their contribution could 
not be included in our assessment. Corridor habitats facilitate the movement of the indicator species, provide protection from predators, and are characterized by relatively high levels of soil moisture as required by amphibians. In the BTLN, corridor habitats for our indicator species comprise various grass communities with different degrees of moisture and a wood cover of less than $10 \%$ [27]. Due to very similar requirements, the classification of biotopes as reproduction or corridor habitats was identical for all three indicator species. A list of the habitat types in BTLN that comprise each class can be found in Appendix A.

\subsection{Assessing the Contribution of Kettle Holes to Amphibian Habitat Provision and Habitat Connectivity}

Following the definition of the biotope types, the contribution of the kettle holes to amphibian habitat provision and connectivity was assessed through comprehensive spatial analyses performed with ArcGIS 10.6.1 and ArcGIS Pro. A detailed description of the spatial analyses performed, including scenario implementation, cluster calculation, and identifying suitable areas for establishing stepping stone habitats, is provided in Appendix B.

\subsubsection{Contribution of Kettle Holes to Habitat Provision}

To analyze the relative contribution of kettle holes to habitat provision, we assessed the number, total area, and average habitat size of reproduction habitats and of kettle holes in the three research areas. Because most kettle holes are very small and therefore only mapped as point objects in the BTLN (no information on spatial extent is provided), we estimated total kettle hole area by multiplying kettle hole numbers with an average size value derived from data for 70 kettle holes in Märkisch-Oderland [28].

\subsubsection{Calculating Clusters of Functionally Connected Habitats}

In order to assess the contribution of kettle holes to functional connectivity, a clustering approach was applied, where reproduction habitats between which genetic exchange is possible for our indicator species (i.e., defined by their specified movement range) were combined into habitat clusters. The total number of clusters is used as an indicator of functional connectivity. If all reproduction habitats are assembled into a single cluster, the functional connectivity is perfect as genetic exchange is possible between all habitats. However, if several clusters are formed, habitat fragmentation occurs and the functional connectivity decreases as the movement range of the species does not allow for genetic exchange between the clusters. The ranges were set to $200 \mathrm{~m}$ for garlic toad, $500 \mathrm{~m}$ for firebellied toad, and $1200 \mathrm{~m}$ for European green toad (Table 1). A simplified approach of cluster aggregation was used, assuming that the species can move freely through reproduction habitats, kettle holes, and corridor habitats, while movement through all other habitats is limited to their specified range. To calculate clusters, reproduction habitats, kettle holes, and corridor habitats were assigned buffers corresponding to half of the species' range, i.e., $100 \mathrm{~m}$ for garlic toad, $250 \mathrm{~m}$ for fire-bellied toad, and $600 \mathrm{~m}$ for European green toad. In this way, buffers of two habitats would overlap if the distance between them was smaller than the species' range. If the buffers overlapped, genetic exchange was considered possible and habitats were combined into a single cluster (Figure 2). For example, if the distance between two reproduction habitats was $450 \mathrm{~m}$, the $100 \mathrm{~m}$ buffers would not overlap, whereas the $250 \mathrm{~m}$ buffers and $600 \mathrm{~m}$ buffers would. Therefore, the habitats would be grouped into different clusters for garlic toad, and into a single cluster for fire-bellied toad or European green toad. Since the purpose of this analysis was to assess the contribution of kettle holes to the connectivity of (other) reproduction habitats, kettle holes were treated in the same way as corridor habitats. Clusters without reproduction habitats were removed. 


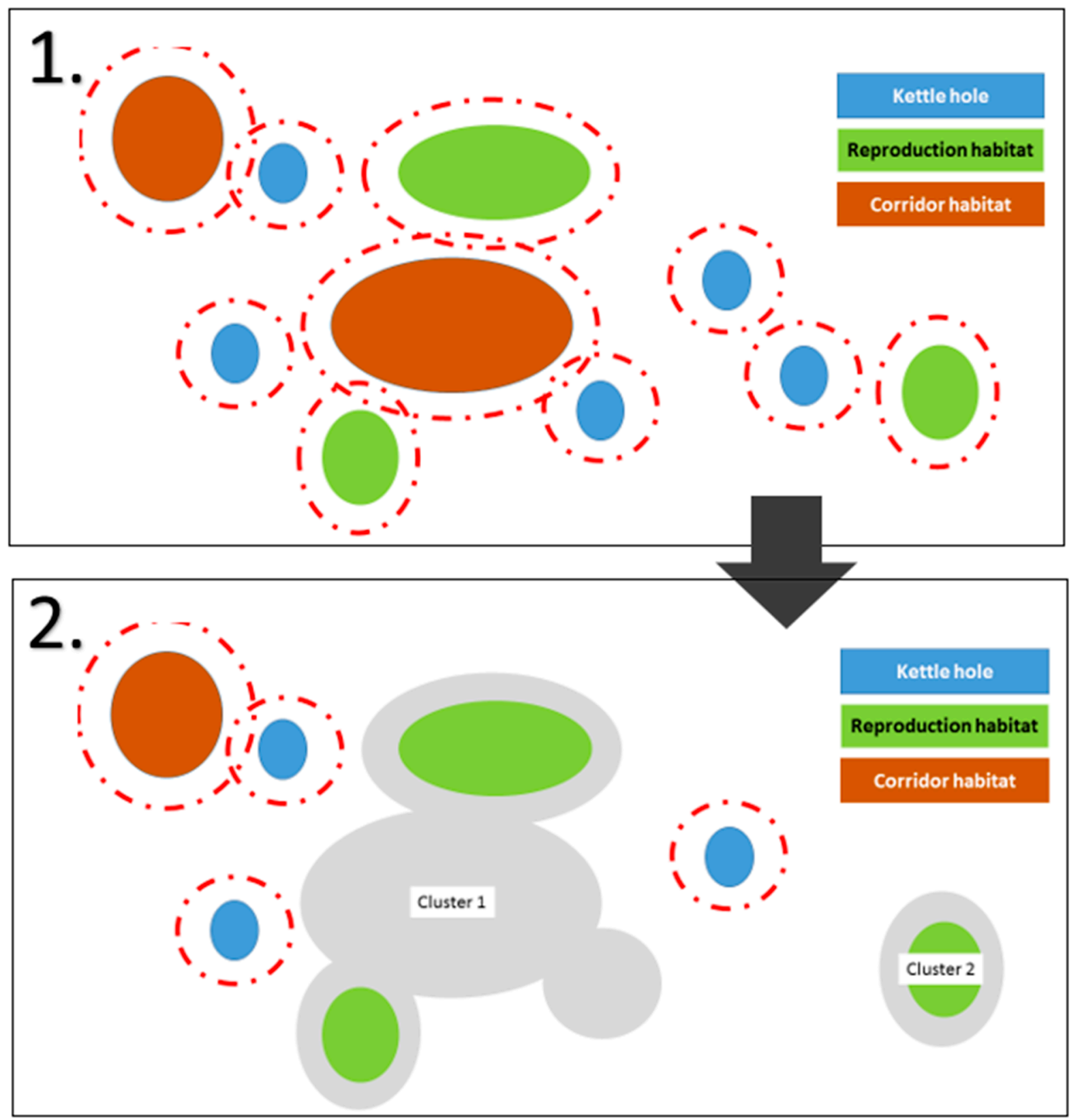

Figure 2. The applied clustering approach, where kettle holes (blue), other reproduction habitats (green), and corridor habitats (brown) were assigned buffers corresponding to half of the indicator species' range (1). Where buffers overlapped, habitats were combined into a cluster. Only clusters containing at least one reproduction habitat were considered (2).

\subsubsection{Scenarios for Assessing the Contribution of Kettle Holes to Habitat Connectivity}

In order to assess the relative contribution of kettle holes to the functional connectivity of amphibian habitats, the clustering was performed for four scenarios. The scenarios represent: (i) the current landscape situation (current state); (ii) the same landscape without kettle holes (without kettle holes); (iii) the same landscape without corridor habitats (without corridors), and (iv) the same landscape without kettle holes and without corridor habitats (without kettle holes and corridors).

\subsection{Identification of Potential Areas for Artificial Stepping Stone Biotopes}

Building on our clustering approach, we identified the areas where the establishment of artificial stepping stone biotopes would connect clusters and increase the functional 
connectivity for our indicator species. Because this step goes beyond analyzing the role of kettle holes for functional connectivity and is intended for real-life applications, and because kettle holes are obviously habitats where amphibians can reproduce, we also included clusters that contained kettle holes but no other reproduction habitats. Clusters were again assigned buffers corresponding to half the indicator species' range, i.e., $100 \mathrm{~m}$ for garlic toad, $250 \mathrm{~m}$ for fire-bellied toad, and $600 \mathrm{~m}$ for European green toad. The areas where buffers overlapped were identified as possible locations for artificial stepping stone biotopes (Figure 3). Artificially established biotopes in any other location would not be able to connect clusters.

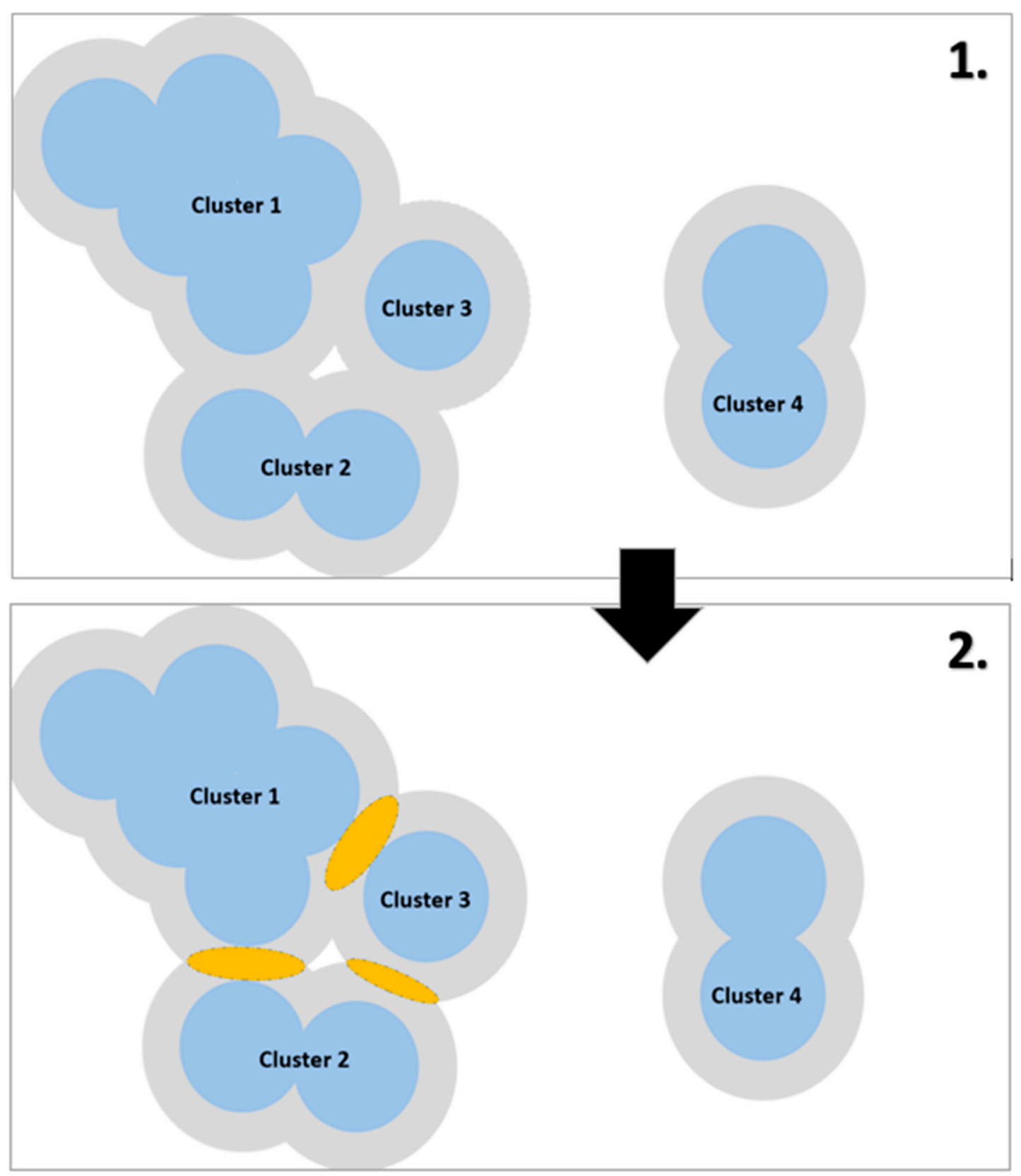

Figure 3. The method used to identify areas where artificial stepping stone biotopes could be created to improve functional connectivity for the studied species. Habitat clusters were assigned buffers corresponding to half of an indicator species' movement range (grey) (1). In areas where buffers overlap (orange), the creation of artificial stepping stone biotopes would connect clusters and improve functional connectivity (2). 


\section{Results}

\subsection{Importance of Kettle Holes for Amphibian Habitat Provision}

The three research areas differ strongly with regard to the number of reproduction habitats and kettle holes (Table 2). While we counted 60 reproduction habitats in Uckermark and 69 in Märkisch-Oderland, the number in Prignitz was only 32. However, the average size of these habitats is also different, so that the total area of reproduction habitats is smallest in Uckermark (18 ha), whereas it is 38 ha in Märkisch-Oderland and 52 ha in Prignitz. The high value for Prignitz is mainly due to a single lake with an area of 34.5 ha.

Table 2. The total area (ha) and number of kettle holes and of other wetland habitats suited for the reproduction of amphibian species in Uckermark, Märkisch-Oderland, and Prignitz. Data for kettle holes refer to perennial kettle holes only; their total area was estimated based on their number and an average size value derived from Hoffmann et al. [26].

\begin{tabular}{ccccccc}
\hline \multirow{2}{*}{ Study Sites } & \multicolumn{2}{c}{ Kettle Holes } & \multicolumn{2}{c}{$\begin{array}{c}\text { Reproduction Habitats } \\
\text { (Excluding Kettle Holes) }\end{array}$} & \multicolumn{2}{c}{ Corridor Habitats } \\
& Total Area (ha) & Count & Total Area (ha) & Count & Total Area (ha) & Count \\
\hline Uckermark & 56.4 & 490 & 17.8 & 60 & 1267.6 & 743 \\
Märkisch-Oderland & 29.2 & 254 & 38.3 & 69 & 1264.8 & 750 \\
Prignitz & 26.3 & 229 & 52.1 & 32 & 495.7 & 526 \\
\hline
\end{tabular}

The number of kettle holes also differs strongly between the research areas. With 490 kettle holes, Uckermark has nearly twice as many kettle holes as Märkisch-Oderland (254) or Prignitz (232). In all three areas, however, kettle holes play a highly important role for providing amphibian habitats. The total number of kettle holes is much higher than that of (other) reproduction habitats, while their total area exceeds (Uckermark) or is on a similar level as the area of reproduction habitats (Märkisch-Oderland, Prignitz). Additionally, their relatively smaller size also means that the ratio of shore vs. open water is much more on the side of the shore, which is favorable for amphibians. We therefore argue that, even where the total area of kettle holes is lower than that of reproduction habitats, they may be able to outperform them with regard to providing habitats for amphibians.

\subsection{Importance of Kettle Holes for Habitat Connectivity}

The functional connectivity for the three indicator species was assessed based on the number of habitat clusters. The higher the number of disconnected clusters, the lower the functional connectivity and vice versa. We used scenarios to assess the current state of functional connectivity and to assess the relative contribution of kettle holes and corridor habitats to this connectivity.

The degree of functional connectivity differed strongly depending on species' range. In the current state, for the short-range species garlic toad, there was strong habitat fragmentation indicated by a high number of clusters. In Uckermark, the 60 reproduction habitats formed 34 clusters; in Märkisch-Oderland, 69 reproduction habitats formed 23 clusters, and in Prignitz, 32 reproduction habitats formed 15 clusters. For the mid-range species fire-bellied toad, functional connectivity was much higher. In Uckermark, only two clusters were formed, while in Märkisch-Oderland and Prignitz, there were still six clusters each. For the long-range species European green toad, in all three research areas, habitats were contained in a single cluster, indicating perfect connectivity (Figure 4). 


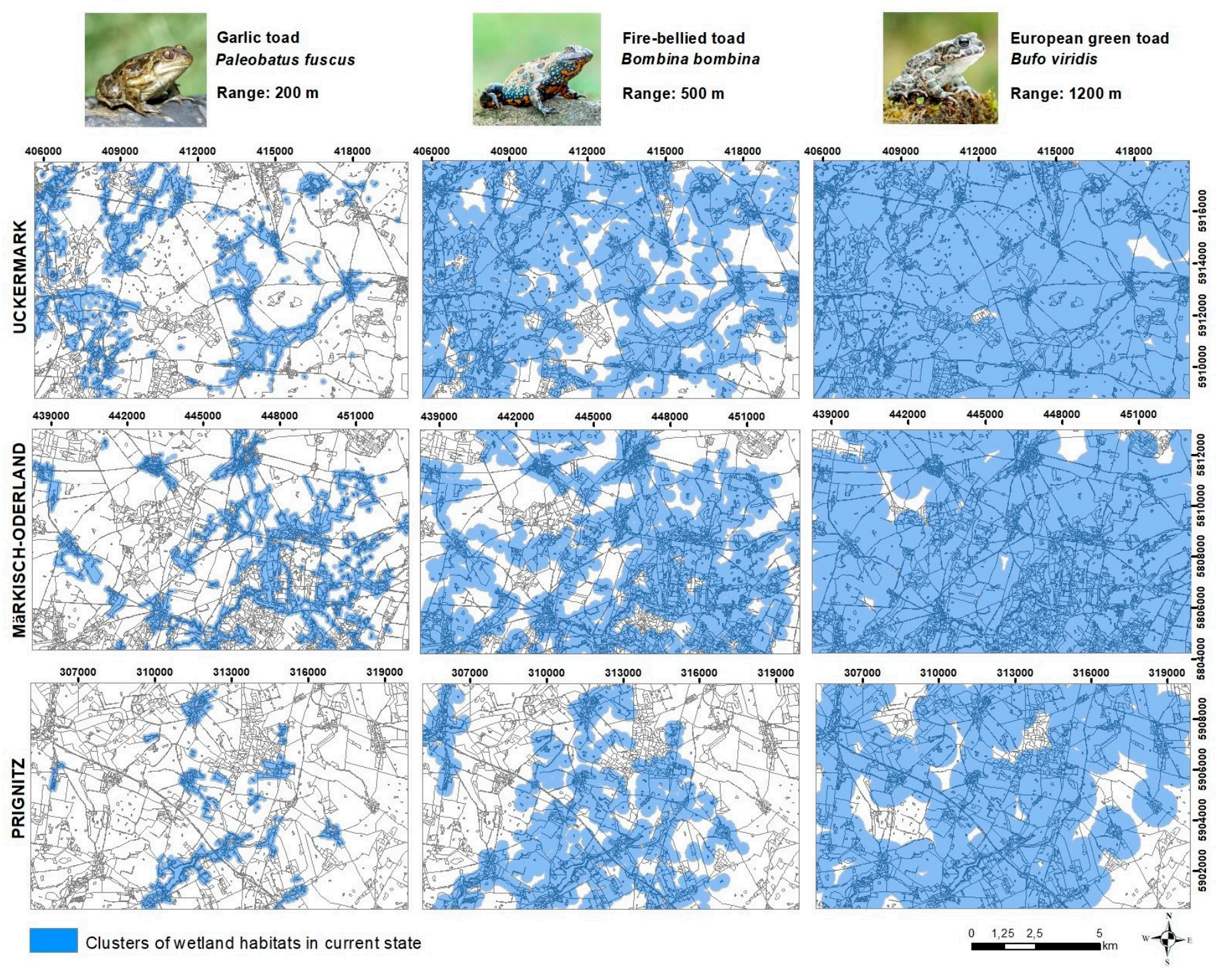

Figure 4. Habitat clusters for garlic toad (range of $200 \mathrm{~m}$ ), fire-bellied toad (500 m), and European green toad (1200 m) at the current state in Uckermark, Märkisch-Oderland, and Prignitz. The clusters represent areas within which genetic exchange is considered possible for the species. The lower the number of clusters, the higher the degree of functional connectivity.

The relative contribution of kettle holes and corridor habitats to functional connectivity also differed strongly depending on species' range (Figure 5).

For the short-range species garlic toad, we found that the contribution of kettle holes was generally low. In scenarios where they were removed, the number of clusters increased only slightly (1-4 additional clusters). By comparison, the contribution of corridor habitats was much higher in both Uckermark and Märkisch-Oderland, where their removal resulted in 16 and 21 additional clusters, respectively. In Prignitz, the removal of corridor habitats only had a minor effect (two additional clusters). Redundancy between the contribution of kettle holes and corridor habitats was negligible, as scenarios where both corridor habitats and kettle holes were removed did not add more than one cluster compared to scenarios where only corridor habitats were removed. 
60

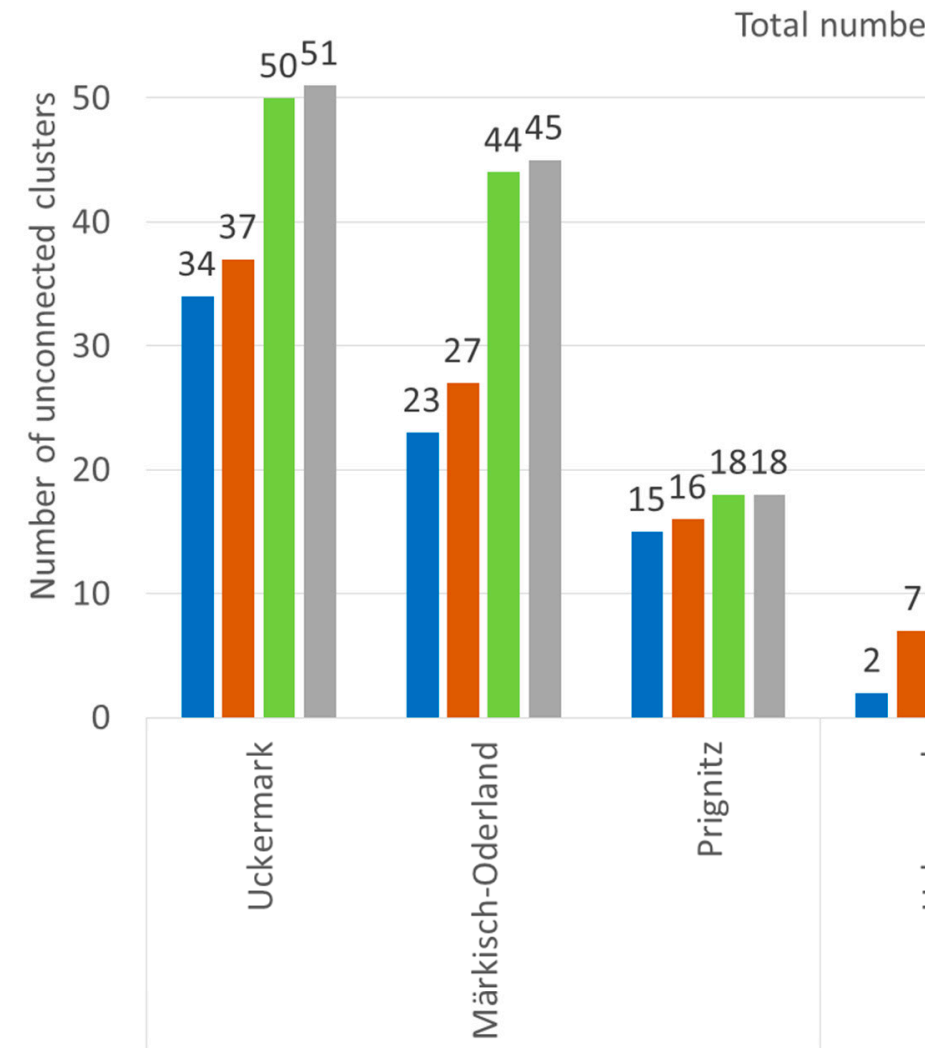

Garlic toad - 200m
36

18

28

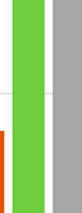

6

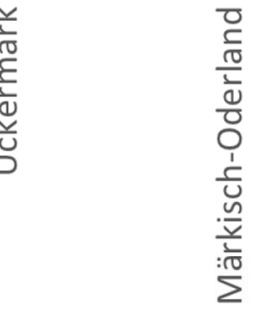

Fire-bellied toad - 500 m

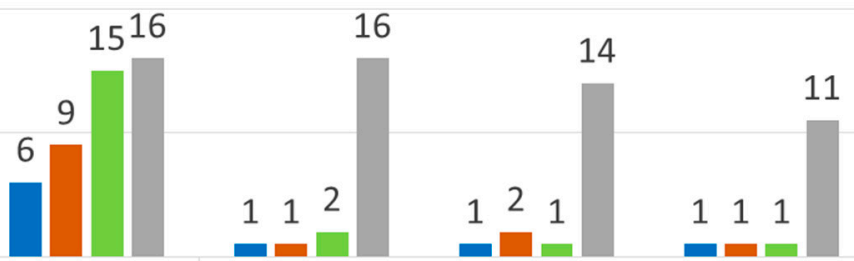

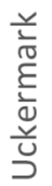

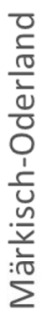

European toad - $1200 m$

- Current situation

Scenario without kettle holes

Scenario without corridors

Scenario without kettle holes and corridor habitats

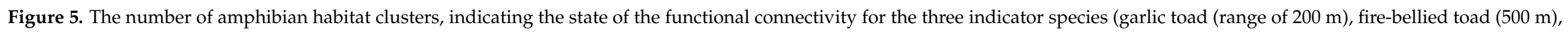
and European green toad $(1200 \mathrm{~m})$ ) at the current state and for the three scenarios (i) without corridors, (ii) without kettle holes, and (iii) without kettle holes and corridor habitats. 
For the medium-range species fire-bellied toad, the contribution of kettle holes was still low, especially when compared with the contribution of corridor habitats. If kettle holes were removed, the number of clusters increased by five in Uckermark, one in MärkischOderland, and three in Prignitz. The removal of corridor habitats increased the number of clusters more strongly by 9-16 additional clusters. We found a strong redundancy in the contribution of kettle holes and corridor habitats in Uckermark. The scenario where both kettle holes and corridor habitats were removed had 18 additional clusters compared to the scenario where only the corridor habitats were removed. This effect was much weaker in Märkisch-Oderland (six additional clusters) and negligible in Prignitz (one additional cluster).

For the long-range species European green toad, the contribution of kettle holes and corridor habitats was high but mostly redundant. Removing either kettle holes or corridor habitats did not increase the total number of clusters to more than two, while, in the scenario where they were both removed, the total numbers were 16 in Uckermark, 14 in Märkisch-Oderland, and 11 in Prignitz.

\subsection{Identifying Priority Areas for Improving Functional Connectivity}

While the applied clustering approach was designed to analyze the state of functional connectivity in the three research areas, it can also be used for identifying areas where the creation of artificial reproduction or corridor habitats would improve functional connectivity. As proof of concept, the analysis was conducted for the short-range species garlic toad in the three research areas. Please note that, for this analysis, the number of clusters is higher because also clusters that contained kettle holes but no other reproduction habitats were included. If artificial habitats were created in all identified areas, the number of disconnected clusters would be reduced from 158 to 24 in Uckermark, from 85 to 25 in Märkisch-Oderland, and from 158 in the current situation to 70 in Prignitz (Figure 6). 

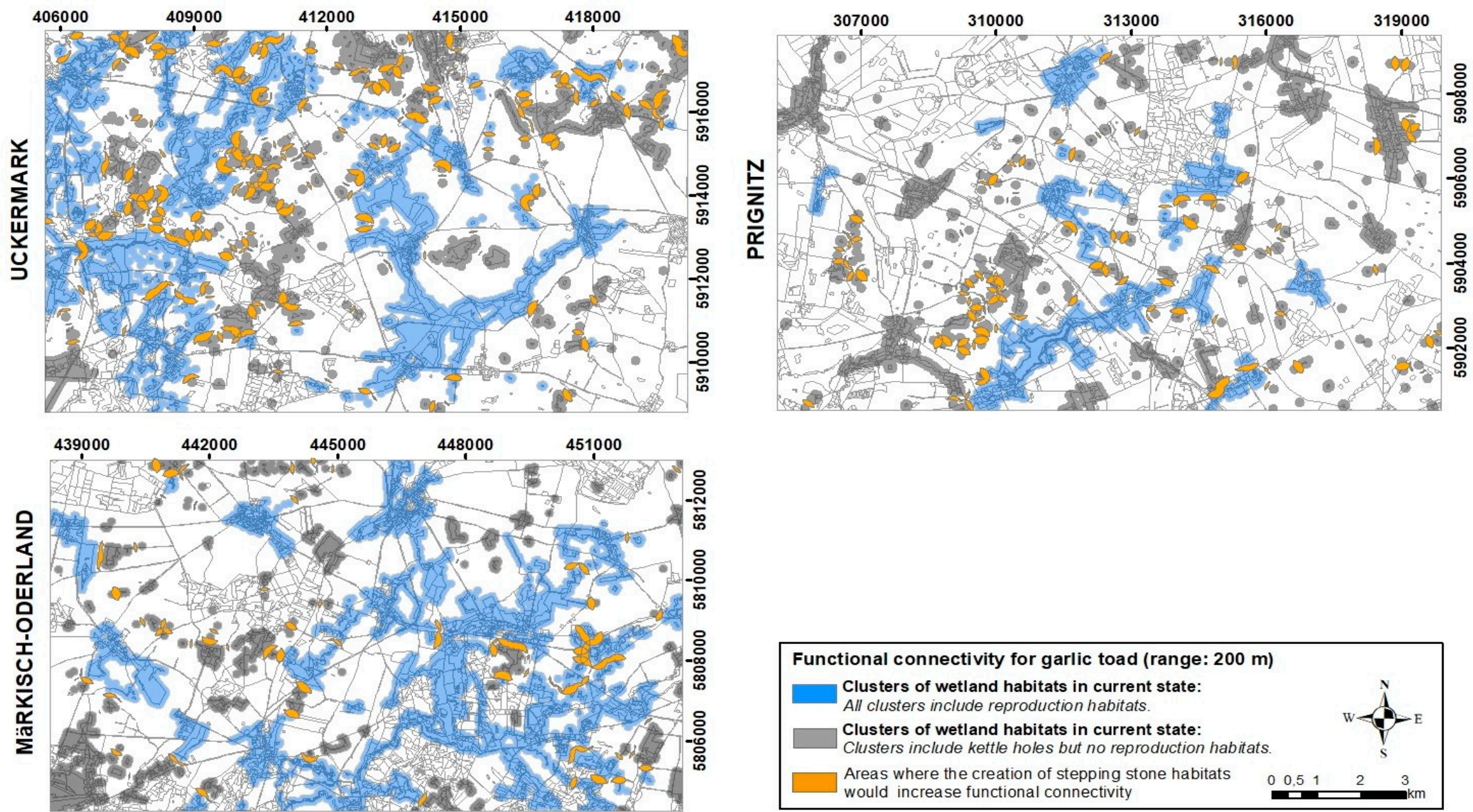

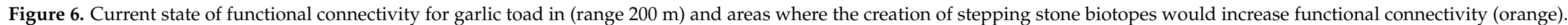




\section{Discussion}

\subsection{Amphibians and Functional Connectivity}

Amphibian community structure is strongly related to habitat features and habitat connectivity [29]. Therefore, habitat loss and fragmentation are among the largest threats to amphibian populations [14,30]. If the current trends of landscape homogenization continue, it is likely that only mobile and opportunistic species will be able to persist. In order to understand population- and species-level implications, it is necessary to shift from site-specific analyses to assessments at the landscape scale. For example, in an empirical movement study in Northern France, the dispersal of amphibians was strongly influenced by the loss of grassland habitats that served as priority movement corridors [31]. A better understanding of amphibian movement ecology is a missing component for counteracting population declines [32].

\subsection{Methods for Measuring Functional Connectivity}

Several other methods exist for assessing functional connectivity in complex landscapes. Least-Cost Path (LCP) analysis (e.g., [33,34]), Circuit Theory (CT) (e.g., [35]), and Graph Theory (GT) (e.g., [36]) are among the most common ones. Both LCP and CT are based on assigning each habitat type a so-called "resistance value", representing the difficulty or danger associated for a target species with traveling through it. The distance traveled through a habitat is multiplied by its resistance value, and the sum of all weighted segments of a path is recorded in LCP. GIS-based optimization is then used to identify the pathways between habitats that have the lowest cost. Instead of identifying the optimal pathway, CT assesses multiple pathways in parallel. Just as the strength of electrical flow through a heterogeneous surface will depend on the resistance values of the respective locations, the intensity of movement of organisms through a landscape is considered to be determined by the habitat's resistance value. LCP and CT analyses are powerful tools to predict the locations of movement corridors and to assess the relative importance of patches and landscape connectivity patterns. Using both methods together has been suggested as a comprehensive approach for corridor identification [37]. Such an identification of movement corridors is well suited for animals moving in herds or creating tracks. Individuals may explore to determine the optimal route, which other animals follow. However, the approach may be less fitting for amphibians who move individually. Under real-life conditions, amphibians cannot recognize the shortest route but will appropriate habitats such as kettle holes if they are within their movement range.

GT uses an abstracted model of the landscape where the habitats relevant for a species are interpreted as "nodes". These nodes are either isolated or connected by "edges" (vertices) to their nearest neighbor. Whether or not a connection exists depends on the movement range of the target species and may be based either on Euclidean distances or, as in LCP or CT, resistance values for different habitats (e.g., [38]). Connectivity is assessed based on the resulting network or networks, particularly by considering the number of connected nodes. Compared to our method, GT has the advantage of directly showing which habitats are connected, but it does not show by what route they are connected, i.e., what areas may be traversed. Our clustering approach, on the other hand, gives detailed information on the areas through which movement may occur.

Approaches based on assigning resistance values to all habitat types require detailed knowledge of species behavior and critical threshold values, which is not always available. Ideally, resistance values should account for obstacles (roads, settlements, etc.) and site-level environmental inputs (i.e., relief classes, topography) insofar as they affect the movement of the species [39]. In this regard, our method constitutes a simplified approach with a binary weighing system. We set the resistance value for reproduction habitats, kettle holes, and corridor habitats to zero, while all other habitats received a resistance value of one. Unlike LCP or CT, our method resets the travel cost once an individual reaches one of the zero-resistance habitats. This reflects amphibian habitat requirements, 
as amphibians can live and forage indefinitely in these habitats and require open water bodies only for their reproduction. Our method provides an overview of connectivity with modest requirements for species data, expertise in landscape ecology, or computing. One of the strengths of this approach lies in its flexibility. It can readily be transferred to other species and landscapes as long as habitat needs and species ranges are adapted accordingly. Identifying areas suitable for improving connectivity is another strength of the approach since this task is far more complex with alternative methods. Where more precise calculations are required, our method can be modified to account for obstacles to movement, such as roads, wide rivers, or steep slopes, or to limit the distance that animals can travel through corridor habitats. A digital elevation model should be included in areas where the terrain is very uneven, such as mountainous regions. However, all this would come at the price of higher data and computing requirements. For this study, the precision of the current approach was considered sufficient.

\subsection{Contribution of Kettle Holes to Habitat Provision and Habitat Connectivity}

The dataset we used only includes kettle holes that are classified as perennial water bodies. Therefore, our calculations could not account for the contribution of kettle holes that are filled with water in some years but dry in others (ephemeral kettle holes), and our results should thus be interpreted as a conservative estimate.

\section{Habitat Provision}

Within our research areas, kettle holes play a highly important role for habitat provision. Their small average size is compensated by their high number. Furthermore, a small size also indicates a high shoreline to water ratio, which is favorable for amphibians. Overall, the contribution of kettle holes in our research areas is on par with, or even exceeds, that of other reproduction habitats, such as lakes or reed beds.

However, it is important to note that their smaller relative size also makes them more susceptible to pollution or drying up, which reduces their ability to provide reproduction habitats for amphibians. In many regions, climate change is likely to increase the frequency and duration of this drying up, potentially resulting in a permanent loss of some kettle holes [3]. Perennial kettle holes may become ephemeral. Accordingly, in a study on 75 kettle holes in Märkisch-Oderland, Hoffmann et al. [28] found that most of the kettle holes classified as perennial in 1993 had to be classified as temporarily water-filled in a very dry year (2020).

\section{Habitat Connectivity}

We found that the current state of functional connectivity depended strongly on species' range. While for the short-range species garlic toad the landscape presented itself as highly fragmented, for the long-range species European green toad all reproduction habitats were part of a single cluster. The effect of range dependency of connectivity is well known and has already been discussed in earlier studies, such as the one by Bunn et al. [19]. However, we found that also the relative importance of kettle holes for habitat connectivity depends on a species' range. For the short-range species, kettle holes were by far less important for functional connectivity than corridor habitats, which are more numerous and have a larger total area. For the long-range species, kettle holes were able to function as connectors of wetland habitats. Even in the scenario where corridor habitats were removed, the total number of clusters was two or lower in all research areas. The contributions of kettle holes and corridor habitats to the functional connectivity of the long-range species were mostly redundant. This redundancy can be interpreted as a safeguard against future fragmentation, as the loss of individual habitats (kettle holes or corridor habitats) would not automatically reduce functional connectivity.

We were able to show how our clustering approach can be applied to identify areas where the creation of stepping stone habitats would connect clusters and thereby improve functional connectivity. However, it is important to note that locations need to fulfill multiple requirements in order to be suitable for the creation of artificial stepping stone 
habitats. While our approach can help to focus the investigation for possible sites, it must be complemented by further local assessments.

\section{Ecosystem Services}

While kettle holes provide multiple ecosystem services, a review by Vasić et al. [3] shows that the service most often addressed in journal articles is their supply of nursery populations and habitats. This service also includes the protection of gene pools. However, the positive contributions of kettle holes are frequently overlooked by farmers, since small wetlands are often considered problematic in terms of agricultural productivity [40,41]. Negative effects of crop management on farmland biodiversity have been noted, as farmland intensification has led to a severe decline in the diversity of amphibians in the vicinity of kettle holes [14].

The supply of habitats for amphibians provided by kettle holes is determined by water availability and by wet and dry cycles. Therefore, any disturbances that affect water availability or lead to longer dry cycles may endanger the supply of this ecosystem service. Conversely, improving functional connectivity may support its supply.

\subsection{Climate Change in Relation to Habitat Provision and Connectivity by Kettle Holes}

Amphibians are extremely sensitive to climate change, mostly because of their low mobility and strict physiological constraints [42,43]. Habitat loss and fragmentation combined with recent climate change have endangered many amphibian species $[30,42,44]$, while various studies predict further huge habitat losses under climate projections [45,46]. Additionally, future climate changes connected to warming and an increase in the intensity and duration of drought periods may have strong negative impacts for amphibians through creating less suitable environmental conditions [42,47].

Therefore, conservation needs to include climate change adaptation. The connectivity of suitable habitat for species migration and dispersal is critical for successful adaptation to climate change through shifting species range boundaries [48,49]. This is consistent with findings by Hodgson et al. [50], who state that increasing connectivity through increasing habitats should be the most recommended option for conservation in the face of climate change. Furthermore, Heller and Zavaleta [51] highlight maintaining connectivity as an important strategy for conserving species diversity in a changing climate. Consequently, it is important to focus on habitats that create a diversity of microclimates (such as kettle holes), as they can buffer the effects of climate change, giving species more possibilities and time to adapt to the changing climate [52,53].

Considering the effects of climate change, the size and depth of kettle holes are likely to play a significant role. Kettle holes with a smaller surface will probably dry out sooner than those with a larger surface and longer dry cycles [4]. This further indicates the importance of kettle holes with a larger area, as they will be able to provide favorable habitat conditions for a longer time. In this regard, it is desirable to connect potential kettle holes of smaller sizes with larger ones, since, in accordance with the predicted climate changes, this may provide a "safe road" for amphibians to migrate from smaller to larger kettle holes during unfavorable conditions.

\subsection{Decision Support for Landscape and Spatial Planning}

Environmental and spatial development based on an ecosystems approach facilitates finding more feasible biodiversity protection strategies where desired land use and required ecosystem services are combined [54]. Regarding potential improvements of ecosystem service supply, mapping and prioritizing areas for conservation strategies would allow the negative impacts of land use and climate change to be minimized [55]. The clustering approach used in this paper enables the identification of areas where the creation of stepping stone biotopes would decrease habitat fragmentation and improve the functional connectivity of target species. Our results show that only a small share of the landscape would be suitable for this purpose. Hence, the identification of such areas is crucial for environmental protection authorities in order to facilitate spatially targeted environmental 
restoration and protection measures. Where biotope mapping is available, this approach can be implemented at various scales across various landscapes.

Likewise, mapping priority areas for biodiversity conservation would facilitate a better understanding of decision-making processes, hence, contributing to an open dialogue among stakeholders [56,57]. The mapping approach used in this study could be integrated into decision-making processes. However, participatory ecosystem-based wetland landscape and spatial development still lacks a conceptual model for spatially explicit, monetary or non-monetary valuation of ecosystem services and their trade-offs, which is an obstacle to stakeholder cooperation.

Result-based payments for amphibian populations on farms could be a way to motivate farmers to not only apply measures for improving connectivity, but also to adapt their management in favor of amphibian biodiversity [3]. Monitoring and assessment tools should aim for minimal financial and bureaucratic requirements [3] in order to achieve a high degree of farmers' participation. Furthermore, integrated and participatory stakeholder activities for the identification of suitable policy measures based on the mapping of ecosystem services are desirable. Such measures could make a significant contribution to sustainable land management and the sustainable use of natural resources.

\section{Conclusions}

In agricultural landscapes that are characterized by a high number of kettle holes, kettle holes play a highly important role for the provision of amphibian habitats. This contribution is on par with, or even exceeds, the contribution of other reproduction habitats, such as lakes or reed beds. In our research areas, the high number of kettle holes more than compensated for their small average size, while their high shoreline to water ratio was considered favorable for amphibians.

The importance of kettle holes as stepping stones, i.e., for functionally connecting other reproduction habitats, strongly depended on species' range. For the short-range amphibian species garlic toad, the contribution of kettle holes to functional connectivity was much lower than the contribution of corridor habitats. For the long-range species European green toad, the contributions of kettle holes and corridor habitats were equally strong, though mostly redundant.

The clustering approach applied in this paper was suitable to assess the current state of functional connectivity for three amphibian species with different movement ranges and to quantify the contribution of kettle holes. We demonstrated how the approach can be used to identify locations suited to improving functional connectivity. As our method has low data and computing requirements and can easily be transferred to other species, it could be a valuable tool for landscape planners and environmental protection agencies.

Author Contributions: Conceptualization, C.P.; methodology, C.P.; formal analysis, B.S., C.P.; writing-original draft preparation, B.S., A.E., C.D., F.V., M.G., C.P.; writing-review and editing, B.S., A.E., C.D., F.V., M.G., C.P.; visualization, B.S., A.E., C.D.; F.V., C.P.; supervision, A.E., C.P. All authors have read and agreed to the published version of the manuscript.

Funding: The work of B.S. was funded by German Federal Foundation for the Environment (Deutsche Bundesstiftung Umwelt-DBU) through their fellowships program for university graduates from Central and Eastern Europe (CEE).

Acknowledgments: The research presented in this paper is part of a three-year, multidisciplinary research project on kettle holes in agricultural landscapes at the Leibniz Centre for Agricultural Landscape Research (Project SWBTrans: "Intelligent use of heterogeneities in agricultural landscapes", https: / / tinyurl.com/2ys5kr2p). We would like to thank Katharina Helming, Marlene Pätzig, and three anonymous reviewers for their helpful comments and suggestions, We also thank Shehra Nowroz and Sebastian Weigl for their help with the formatting of the manuscript. Their contributions are greatly appreciated. 
Conflicts of Interest: The authors declare no conflict of interest. Filip Vasić is an employee of MDPI but did not work for the journal Land during the preparation, submission, or publication of this article.

\section{Appendix A}

This appendix lists the habitat categories used in this study and a translation of the habitat types that they comprise within the Brandenburg classification of biotope types.

Appendix A.1. Reproduction Habitats

\begin{tabular}{|c|c|c|}
\hline $\begin{array}{l}\text { BIOTYP } \\
\text { Code }\end{array}$ & $\begin{array}{l}\text { BIOTYP8 } \\
\text { Code }\end{array}$ & $\begin{array}{c}\text { BIOTYP8_T } \\
\text { (Text_Description) }\end{array}$ \\
\hline 02100 & 02100000 & Lakes \\
\hline 02130 & 02130000 & Temporary small water bodies \\
\hline 02140 & 02140000 & Water reservoirs \\
\hline 02150 & 02150000 & Ponds \\
\hline 02161 & 02161000 & Waters in peat ditches \\
\hline 02200 & 02200000 & Floating leaf and submerged plant communities in standing waters. \\
\hline 02210 & 02210000 & Reed communities at standing waters \\
\hline 02211 & 02211000 & Tall reed fens at standing waters \\
\hline 022111 & 02211100 & Tall reed fens on standing waters; reed canary grass \\
\hline 022112 & 02211200 & Tall reed fens on standing waters; Cat-tail reed-beds. \\
\hline 0513101 & 05131010 & Grassland fallows of moist sites; largely without spontaneous woody vegetation $(<10 \%$ woody cover). \\
\hline
\end{tabular}

\section{A.2. Kettle Holes}

\begin{tabular}{ccc}
$\begin{array}{c}\text { BIOTYP } \\
\text { Code }\end{array}$ & $\begin{array}{c}\text { BIOTYP8 } \\
\text { Code }\end{array}$ & $\begin{array}{c}\text { BIOTYP8_T } \\
\text { (Text_Description) }\end{array}$ \\
\hline 02120 & 02120000 & Perennial small water bodies (kettle holes potholes, mudholes, etc., $<1$ ha) \\
\hline
\end{tabular}

\section{A.3. Corridor Habitats}

\begin{tabular}{|c|c|c|}
\hline $\begin{array}{l}\text { BIOTYP } \\
\text { Code }\end{array}$ & $\begin{array}{l}\text { BIOTYP8 } \\
\text { Code }\end{array}$ & $\begin{array}{c}\text { BIOTYP8_T } \\
\text { (Text_Description) }\end{array}$ \\
\hline 05150 & 05150000 & Intensive grassland incl. intensive pastures \\
\hline 051601 & 05160100 & Ornamental lawn/shear grass; largely without trees. \\
\hline 051602 & 05160200 & Ornamental lawn/shear grass; with loosely standing trees. \\
\hline 0510001 & 05100010 & Wet meadows and wet pastures; largely without spontaneous woody vegetation ( $<10 \%$ woody cover). \\
\hline 0510101 & 05101010 & Tall sedge meadows (litter meadows); largely without spontaneous woody vegetation ( $<10 \%$ woody cover). \\
\hline 0510301 & 05103010 & Wet meadows of nutrient-rich sites; largely without spontaneous woody vegetation ( $<10 \%$ woody cover). \\
\hline 0510501 & 05105010 & Wet pastures; largely without spontaneous woody vegetation $(<10 \%$ woody cover). \\
\hline 0511001 & 05110010 & Mesotrophic grasslands; largely without spontaneous woody vegetation(<10\% woody cover). \\
\hline 0511002 & 05110020 & Mesotrophic grasslands with spontaneous woody vegetation(10-30\% woody cover). \\
\hline 0511101 & 05111010 & Mesotrophic pastures, fat pastures; largely without spontaneous woody vegetation (<10\% woody cover). \\
\hline 0511102 & 05111020 & Mesotrophic pastures, fat pastures; with spontaneous woody vegetation (10-30\% woody cover). \\
\hline 0511201 & 05112010 & Mesotrophic meadows; largely without spontaneous woody vegetation(<10\% woody cover). \\
\hline 0511202 & 05112020 & Mesotrophic meadows; with spontaneous woody vegetation(10-30\% woody cover). \\
\hline 0513001 & 05130010 & Grassland fallows; largely without spontaneous woody vegetation( $<10 \%$ woody cover). \\
\hline 0513002 & 05130020 & Grassland fallow; with spontaneous woody vegetation(10-30\% woody cover). \\
\hline 0513101 & 05131010 & Grassland fallows of moist sites; largely without spontaneous woody vegetation (<10\% woody cover). \\
\hline
\end{tabular}




\begin{tabular}{|c|c|c|}
\hline $\begin{array}{l}\text { BIOTYP } \\
\text { Code }\end{array}$ & $\begin{array}{l}\text { BIOTYP8 } \\
\text { Code }\end{array}$ & $\begin{array}{l}\text { BIOTYP8_T } \\
\text { (Text_Description) }\end{array}$ \\
\hline 0513102 & 05131020 & Grassland fallows of moist locations; with spontaneous woody vegetation(10-30\% woody cover). \\
\hline 0513111 & 05131110 & $\begin{array}{l}\text { Grassland fallows of moist sites; dominated by reeds; largely without spontaneous woody vegetation }(<10 \% \text { woody } \\
\text { cover). }\end{array}$ \\
\hline 0513112 & 05131120 & Grassland fallows of wet sites; dominated by reeds; with spontaneous woody vegetation (10-30\% woody cover). \\
\hline 0513201 & 05132010 & Grassland fallows of mesotrophic sites; largely without spontaneous woody vegetation (<10\% woody cover). \\
\hline 0513202 & 05132020 & Grassland fallows of mesotrophic sites; with spontaneous woody vegetation (10-30\% woody cover). \\
\hline 0513301 & 05133010 & Grassland fallows of dry sites; largely without spontaneous woody vegetation (<10\% woody cover). \\
\hline 0513302 & 05133020 & Grassland fallows of dry locations; with spontaneous woody vegetation(10-30\% woody cover). \\
\hline 0514001 & 05140010 & Herbaceous meadows and shrublands; largely without spontaneous woody vegetation (<10\% woody cover). \\
\hline 0514101 & 05141010 & $\begin{array}{l}\text { Tall forb communities of moist to wet sites; largely without spontaneous woody vegetation }(<10 \% \text { woody } \\
\text { vegetation cover). }\end{array}$ \\
\hline 0514102 & 05141020 & Tall forb communities of moist to wet sites; with spontaneous woody vegetation (10-30\% woody vegetation cover) \\
\hline 0514201 & 05142010 & $\begin{array}{l}\text { Herbaceous vegetation (field margins) of fresh, nutrient-rich sites; largely without spontaneous woody vegetation } \\
(<10 \% \text { woody vegetation cover). }\end{array}$ \\
\hline 0514202 & 05142020 & $\begin{array}{l}\text { Herbaceous meadows (field margins) of fresh, nutrient-rich sites; with spontaneous woody vegetation (10-30\% } \\
\text { woody vegetation cover) }\end{array}$ \\
\hline 05120001 & 05120001 & Dry grasslands; largely without spontaneous woody vegetation( $<10 \%$ woody cover $)$. \\
\hline
\end{tabular}

\section{A.4. Dataset}

MLUL (2014) Ministerium für Ländliche Entwicklung, Umwelt und Landwirtschaft des Landes Brandenburg (MLUL). Flächendeckende Biotop- und Landnutzungskartierung (BTLN) im Land Brandenburg - CIR-Biotoptypen 2009, dl-de/by-2-0. Potsdam. https: / / tinyurl.com/xbcm9rvt (accessed on 4 June 2021) [26].

\section{A.5. Habitat Type Classification}

LfU: Brandenburg state office for the environment (2013): Documentation of the Brandenburg land use and biotope mapping 2009. Available online: https:/ / tinyurl.com/ fby8jypk (accessed on 19 March 2021) [27].

\section{Appendix B}

This appendix provides a detailed description of the method for the calculation of habitat clusters and the identification of areas where the creation of stepping stone habitats could improve functional connectivity. All calculations were performed in ArcGIS Pro.

\section{Appendix B.1. Starting Point}

For each of our research areas, we started with three layers representing habitat categories used in our analysis:

- Kettle holes: containing polygon data and point data;

- Reproduction habitats: containing polygon data;

- Corridor habitats: containing polygon data.

There was no overlap between objects within a layer or between objects from different layers. The category "other", representing all areas not falling into either of the above categories, did not have a layer.

\section{Appendix B.2. Assigning Buffers}

For each combination of research area and indicator species, buffers were assigned to all polygons, using BUFFER (Analysis). Objects originally from the kettle hole layer that had been recorded as point data were thereby converted into polygons. Buffer sizes corresponded to half the range assigned to the indicator species and were:

- $100 \mathrm{~m}$ for garlic toad; 
- $250 \mathrm{~m}$ for fire-bellied toad;

- $600 \mathrm{~m}$ for European green toad.

Appendix B.3. Scenario Preparation

In order to create the scenario layers for each research area, layers were either merged into a single scenario layer using MERGE (Data Management) (scenarios 1-3) or a single layer was selected to represent the scenario (scenario 4):

1. Current state: all three layers were merged;

2. Without kettle holes: the layers reproduction habitats and corridor habitats were merged;

3. Without corridors: the layers reproduction habitats and kettle holes were merged;

4. Without kettle holes and without corridor habitats: only the layer reproduction habitats was used, and no merge was necessary.

Appendix B.4. Calculating Clusters

Appendix B.4.1. Combining Polygons

For each combination of research area, scenario layer, and indicator species, we merged polygons if their buffers touched using DISSOLVE BOUNDARIES (GeoAnalytics). The resulting objects are referred to as "clusters" in this manuscript.

Appendix B.4.2. Discarding Clusters without Reproduction Habitats

Because our analysis aimed to quantify the effects of kettle holes and corridor habitats on the functional connectivity between reproduction habitats, all clusters that did not contain any reproduction habitat were discarded.

For each combination of research area, scenario layer, and indicator species, we identified and selected the clusters containing reproduction habitats, using SELECT LAYER BY LOCATION (Data Management). The selected clusters were then saved as a new layer, using LAYER FROM SELECTION (Feature layer tab $->$ data tab). For our analysis, we used these new layers, effectively discarding all clusters that did not contain at least one reproduction habitat. The number of clusters for each combination of research area, scenario layer, and indicator species was used as an indicator for the degree of functional connectivity.

Appendix B.5. Identifying Areas Where the Creation of Stepping-Stone Habitats Could Improve Functional Connectivity

Appendix B.5.1. Re-Clustering

In this analysis, clusters were re-calculated to also include those that contained kettle holes but no reproduction habitats. We followed the steps above but modified step $\mathbf{3 b}$ to select all clusters containing either reproduction habitats and/or kettle holes. We used the merged layer without corridors that contained all reproduction habitat and kettle hole objects and used it as input for SELECT LAYER BY LOCATION (Data Management). The selected clusters were then saved as a new layer, using LAYER FROM SELECTION (Feature layer tab -> data tab). For our analysis, we used these new layers, effectively discarding all clusters not containing either reproduction habitats or kettle holes.

\section{Appendix B.5.2. Assigning Buffers}

For the scenario current state and the indicator species garlic toad within all three research areas, buffers were assigned to the clusters, using BUFFER (Analysis). Buffer sizes corresponded to half the species' range $(100 \mathrm{~m})$.

Appendix B.5.3. Identifying Areas Where Buffers Overlap

For the scenario current state and the indicator species garlic toad within all three research areas, we used INTERSECT (Analysis) to identify areas where buffers overlapped. 
The results (output) are polygons representing areas where the creation of artificial stepping stone habitats would increase functional connectivity.

\section{References}

1. Pätzig, M.; Kalettka, T.; Glemnitz, M.; Berger, G. What governs macrophyte species richness in kettle hole types? A case study from Northeast Germany. Limnologica 2012, 42, 340-354. [CrossRef]

2. Platen, R.; Kalettka, T.; Ulrichs, C. Kettle holes in the agrarian landscape: Isolated and ecological unique habitats for carabid beetles (col.: Carabidae) and spiders (arach.: Araneae). J. Landsc. Ecol. 2016, 9, 29-30. [CrossRef]

3. Vasić, F.; Paul, C.; Strauss, V.; Helming, K. Ecosystem services of kettle holes in agricultural landscapes. Agronomy 2020, 10, 1326. [CrossRef]

4. Lischeid, G.; Kalettka, T. Grasping the heterogeneity of kettle hole water quality in Northeast Germany. Hydrobiologia 2012, 689, 63-77. [CrossRef]

5. Kalettka, T.; Berger, G.; Pfeffer, H.; Rudat, C. Integrated conservation and management of kettle holes in young moraine agricultural landscapes of northeast Germany. In Proceedings of the ICID 21st European Regional Conference, Frankfurt (Oder), Germany, Slubice, Poland, 15-19 May 2005; pp. 1-4.

6. Arponen, A.; Heikkinen, R.K.; Paloniemi, R.; Pöyry, J.; Similä, J.; Kuussaari, M. Improving conservation planning for semi-natural grasslands: Integrating connectivity into agri-environment schemes. Biol. Conserv. 2013, 160, 234-241. [CrossRef]

7. Tews, J.; Brose, U.; Grimm, V.; Tielbörger, K.; Wichmann, M.C.; Schwager, M.; Jeltsch, F. Animal species diversity driven by habitat heterogeneity/diversity: The importance of keystone structures. J. Biogeogr. 2004, 31, 79-92. [CrossRef]

8. Heim, O.; Lorenz, L.; Kramer-Schadt, S.; Jung, K.; Voigt, C.C.; Eccard, J.A. Landscape and scale-dependent spatial niches of bats foraging above intensively used arable fields. Ecol. Process. 2017, 6, 1-15. [CrossRef]

9. Baum, K.A.; Haynes, K.J.; Dillemuth, F.P.; Cronin, J.T. The matrix enhances the effectiveness of corridors and stepping stones. Ecology 2004, 85, 2671-2676. [CrossRef]

10. Thiere, G.; Milenkovski, S.; Lindgren, P.E.; Sahlen, G.; Berglund, O.; Weisner, S.E.B. Wetland creation in agricultural landscapes: Biodiversity benefits on local and regional scales. Biol. Conserv. 2009, 142, 964-973. [CrossRef]

11. Fahrig, L. Effects of Habitat Fragmentation on Biodiversity. Annu. Rev. Ecol. Evol. Syst. 2003, 34, 487-515. [CrossRef]

12. Ferrante, L.; Baccaro, F.B.; Ferreira, E.B.; Sampaio, M.F.D.O.; Santos, T.; Justino, R.C.; Angulo, A. The matrix effect: How agricultural matrices shape forest fragment structure and amphibian composition. J. Biogeogr. 2017, 44, 1911-1922. [CrossRef]

13. Hoffmann, M.; Hilton-Taylor, C.; Angulo, A.; Böhm, M.; Brooks, T.M.; Butchart, S.H.M.; Carpenter, K.E.; Chanson, J.; Collen, B.; Cox, N.A.; et al. The impact of conservation on the status of the world's vertebrates. Science 2010, 330, 1503-1509. [CrossRef]

14. Berger, G.; Pfeffer, H.; Kalettka, T. Amphibienschutz in Kleingewässerreichen Ackerbaugebieten; Nature + Text: Rangsdorf, Germany, 2011; p. 381.

15. Hamm, M.; Drossel, B. Habitat heterogeneity hypothesis and edge effects in model metacommunities. J. Theor. Biol. 2017, 426, 40-48. [CrossRef]

16. Meiklejohn, K.; Ament, R.; Tabor, G. Habitat Corridors \& Landscape Connectivity: Clarifying the Terminology; Center for Large Landscape Conservation: Bozeman, MT, USA, 2010; Available online: https:/ / tinyurl.com/28wcr3s (accessed on 16 February 2021).

17. Herrera, L.P.; Sabatino, M.C.; Jaimes, F.R.; Saura, S. Landscape connectivity and the role of small habitat patches as stepping stones: An assessment of the grassland biome in South America. Biodivers. Conserv. 2017, 26, 3465-3479. [CrossRef]

18. Taylor, P.D.; Fahrig, L.; Henein, K.; Merriam, G. Connectivity is a vital element of landscape structure. Oikos 1993, 68, 571-573. [CrossRef]

19. Bunn, A.G.; Urban, D.L.; Keitt, T.H. Landscape connectivity: A conservation application of graph theory. J. Environ. Manag. 2000, 59, 265-278. [CrossRef]

20. McRae, B.H.; Beier, P. Circuit theory predicts gene flow in plant and animal populations. Proc. Natl. Acad. Sci. USA 2007, 104, 19885-19890. [CrossRef]

21. Churko, G.; Kienast, F.; Bolliger, J. A multispecies assessment to identify the functional connectivity of amphibians in a humandominated landscape. ISPRS Int. J. Geo-Inf. 2020, 9, 287. [CrossRef]

22. Scholz, E. Die Naturräumliche Gliederung Brandenburgs; Pädagogisches Bezirkskabinett: Potsdam, Germany, 1962; p. 92 . (In German)

23. Köstler, H.; Grabowski, C.; Moeck, M.; Saure, C.; Kielhorn, K.-H. Beschreibung der Biotoptypen auf der Grundlage der Liste der Biotoptypen Brandenburgs (Stand 2004) und der Erläuterungstexte (Stand 1994) von Dr. Frank Zimmermann (Landesumweltamt Brandenburg); Arbeitsgemeinschaft Biotopkartierung: Berlin, Germany, 2005; Available online: https:/ / tinyurl.com/4xbadf86 (accessed on 29 June 2021).

24. Amler, K.; Bahl, A.; Henle, K.; Kaule, G.; Poschlod, P.; Settele, J. Populationsbiologie in der Naturschutzpraxis. Isolation, Flächenbedarf und Biotopansprïche von Pflanzen und Tieren; Ulmer: Stuttgart, Germany, 1999.

25. Meinig, H.; Boye, P.; Dähne, M.; Hutterer, R.; Lang, J. Rote Liste und Gesamtartenliste der Säugetiere (Mammalia) Deutschlands. Band 170 (2): Säugetiere; Bundesamt für Naturschutz: Bonn, Germany, 2020; ISBN 978-3-7843-3772-2. 
26. MLUL (2014) Ministerium für Ländliche Entwicklung, Umwelt und Landwirtschaft des Landes Brandenburg (MLUL). Flächendeckende Biotop- und Landnutzungskartierung (BTLN) im Land Brandenburg-CIR-Biotoptypen 2009, dl-de/by-2-0. Potsdam. Available online: https:/ / tinyurl.com/xbcm9rvt (accessed on 4 June 2021).

27. LfU. Brandenburg State Office for the Environment (2013): Documentation of the Brandenburg Land Use and Biotope Mapping 2009. Available online: https:/ / tinyurl.com/fby8jypk (accessed on 19 March 2021).

28. Hoffmann, J.; Wittchen, U.; Wahrenberg, T. Hydrological situation of small water bodies and their avifauna in arable farming areas in eastern Brandenburg with reference to meteorological conditions and yield development. Nat. Landsch.Brandenbg. 2020, 29, 24-45. (In German)

29. Ficetola, G.F.; De Bernardi, F. Amphibians in a human-dominated landscape: The community structure is related to habitat features and isolation. Biol. Conserv. 2004, 119, 219-230. [CrossRef]

30. Cushman, S.A. Effects of habitat loss and fragmentation on amphibians: A review and prospectus. Biol. Conserv. 2006, 128, 231-240. [CrossRef]

31. Arntzen, J.W.; Abrahams, C.; Meilink, W.R.M.; Iosif, R.; Zuiderwijk, A. Amphibian decline, pond loss and reduced population connectivity under agricultural intensification over a 38 year period. Biodivers. Conserv. 2017, 26, 1411-1430. [CrossRef]

32. Pittman, S.E.; Osbourn, M.S.; Semlitsch, R.D. Movement ecology of amphibians: A missing component for understanding population declines. Biol. Conserv. 2014, 169, 44-53. [CrossRef]

33. Carroll, C.; Miquelle, D.G. Spatial viability analysis of Amur tiger Panthera tigris altaica in the Russian Far East: The role of protected areas and landscape matrix in population persistence. J. Appl. Ecol. 2006, 43, 1056-1068. [CrossRef]

34. LaRue, M.A.; Nielsen, C.K. Modelling potential dispersal corridors for cougars in midwestern North America using least-cost path methods. Ecol. Model. 2008, 212, 372-381. [CrossRef]

35. McRae, B. Isolation by resistance. Evol. Int. J. Org. Evol. 2006, 60, 1551-1561. [CrossRef]

36. Minor, E.S.; Urban, D.L. A graph-theory frarmework for evaluating landscape connectivity and conservation planning. Conserv. Biol. 2008, 22, 297-307. [CrossRef]

37. McRae, B.H.; Dickson, B.G.; Keitt, T.H.; Shah, V.B. Using circuit theory to model connectivity in ecology, evolution, and conservation. Ecology 2008, 89, 2712-2724. [CrossRef] [PubMed]

38. Urban, D.; Keitt, T. Landscape connectivity: A graph-theoretic perspective. Ecology 2001, 82, 1205-1218. [CrossRef]

39. Emel, S.L.; Wang, S.; Metz, R.P.; Spigler, R.B. Type and intensity of surrounding human land use, not local environment, shape genetic structure of a native grassland plant. Mol. Ecol. 2021, 30, 639-655. [CrossRef]

40. Kalettka, T.; Rudat, C. Hydrogeomorphic types of glacially created kettle holes in North-East Germany. Limnologica 2006, 36, 54-64. [CrossRef]

41. Acreman, M.C.; Mccartney, M.P. Hydrological Impacts in and around wetlands. In The Wetlands Handbook; Maltby, E., Barker, T., Eds.; Wiley-Blackwell: Chichester, UK, 2009; pp. 643-666.

42. Hof, C.; Araújo, M.B.; Jetz, W.; Rahbek, C. Additive threats from pathogens, climate and land-use change for global amphibian diversity. Nature 2011, 480, 516-519. [CrossRef]

43. Wake, D.B.; Vredenburg, V.T. Are we in the midst of the sixth mass extinction? A view from the world of amphibians. Proc. Natl. Acad. Sci. USA 2008, 105, 11466. [CrossRef]

44. Wood, P.; Greenwood, M.; Agnew, M. Pond Biodiversity and Habitat Loss in the UK. Area 2003, 35, 206-216. [CrossRef]

45. Milanovich, J.R.; Peterman, W.E.; Nibbelink, N.P.; Maerz, J.C. Projected loss of a salamander diversity hotspot as a consequence of projected global climate change. PLoS ONE 2010, 5. [CrossRef] [PubMed]

46. Zank, C.; Becker, F.G.; Abadie, M.; Baldo, D.; Maneyro, R.; Borges-Martins, M. Climate change and the distribution of neotropical red-bellied toads (Melanophryniscus, Anura, Amphibia): How to prioritize species and populations? PLoS ONE 2014, 9, e94625. [CrossRef] [PubMed]

47. Araújo, M.; Thuiller, W.; Pearson, R. Climate warming and the decline of amphibians and reptiles in Europe. J. Biogeogr. 2006, 33, 1712-1728. [CrossRef]

48. McKelvey, K.S.; Copeland, J.P.; Schwartz, M.K.; Littell, J.S.; Aubry, K.B.; Squires, J.R.; Parks, S.A.; Elsner, M.M.; Mauger, G.S. Climate change predicted to shift wolverine distributions, connectivity, and dispersal corridors. Ecol. Appl. 2011, 21, 2882-2897. [CrossRef]

49. Kool, J.T.; Moilanen, A.; Treml, E.A. Population connectivity: Recent advances and new perspectives. Landsc. Ecol. 2013, 28, 165-185. [CrossRef]

50. Hodgson, J.A.; Thomas, C.D.; Wintle, B.A.; Moilanen, A. Climate change, connectivity and conservation decision making: Back to basics. J. Appl. Ecol. 2009, 46, 964-969. [CrossRef]

51. Heller, N.E.; Zavaleta, E.S. Biodiversity management in the face of climate change: A review of 22 years of recommendations. Biol. Conserv. 2009, 142, 14-32. [CrossRef]

52. Hannah, L.; Flint, L.; Syphard, A.D.; Moritz, M.A.; Buckley, L.B.; McCullough, I.M. Fine-grain modeling of species' response to climate change: Holdouts, stepping-stones, and microrefugia. Trends Ecol. Evol. 2014, 29, 390-397. [CrossRef]

53. Anderson, M.G.; Comer, P.J.; Beier, P.; Lawler, J.J.; Schloss, C.A.; Buttrick, S.; Albano, C.M.; Faith, D.P. Case studies of conservation plans that incorporate geodiversity. Conserv. Biol. 2015, 29, 680-691. [CrossRef]

54. SWD. Commission Staff Working Document. EU Guidance on Integrating Ecosystems and Their Services into Decision-Making; European Commission: Brussels, Belgium, 2019. 
55. Ayram, C.A.C.; Mendoza, M.E.; Etter, A.; Salicrup, D.R.P. Habitat connectivity in biodiversity conservation: A review of recent studies and applications. Prog. Phys. Geogr. Earth Environ. 2016, 40, 7-37. [CrossRef]

56. Grêt-Regamey, A.; Siren, E.; Brunner, S.H.; Weibel, B. Review of decision support tools to operationalize the ecosystem services concept. Ecosyst. Serv. 2017, 26, 306-315. [CrossRef]

57. Maes, J.; Egoh, B.; Willemen, L.; Liquete, C.; Vihervaara, P.; Schagner, J.P.; Grizzetti, B.; Drakou, E.G.; La Notte, A.; Zulian, G.; et al. Mapping ecosystem services for policy support and decision making in the European Union. Ecosyst. Serv. 2012, 1, 31-39. [CrossRef] 